\title{
Mikoła Chaustowicz
}

Uniwersytet Warszawski

https://orcid.org/0000-0002-3007-0603

\section{Ігнацы Яцкоўскі як верагодны аўтар верша “За́грай, за́грай, хло́пчэ ма́лы...”"}

Ігнацы Яцкоўскі, пэўна, не быў высокае думкі пра свае паэтычныя здольнасці, пра што аднойчы пасведчыў на пісьме: Owóz ja, chocia $\dot{z}$ i nie poeta...1. Словы гэтыя, праўда, адносіліся да гадоў юнацтва і былі напісаны у 1842 годзе, г. зн. у час, калі толькі літаральна некалькі разой эмігрант паспрабаваў свае сілы ў версіфікацыі. А вось праз нейкі дзясятак гадоў у даробку I. Яцкойскага мелася узжо блізу тысячы вершаваных радкоў, 864 з якіх былі надрукаваны (361 - ананімна), і ён працягваў складаць вершы ледзь не да канца свайго жыцця.

Польскамоўныя вершаваныя творы I. Яцкойскага прасякнуты характэрным для гэтага творцы патрыятызмам, які грунтаваўся на любові да малое Айчыны - Літвы-Наваградчыны і быў адначасна выяўленнем "дзяржаўнага" пачуцця да Рэчы Паспалітае, якую ў той час звычайна атаясамлівалі з Польшчай. Яшчэ больш яскрава дадзеная тэндэнцыйнасць ягонай творчасці выступіла $\ddot{y}$ празаічнай кнізе “Аповесць $з$ майго часу, альбо Літоўскія прыгоды", у якой створаны найцікавейшы малюнак грамадска-палітычнага жыцця на Беларусі пачатку XIX стагоддзя, а таксама пададзены адзін з самых адметных беларускамойных мастацкіх тэкстаў сярэдзіны XIX стагоддзя - верш “За́грай, за́грай, хло́пчэ ма́лы...”.

1 List I. Jackowskiego do L. Niedzwieckiego z 25.04.1842 r., [w:] Rkps. Kór. 2405: Korespondencja Leonarda Niedźwieckiego: Litera J (Jabłoński Leon - Jung A.), 1832-1874, s. $214 \mathrm{v}$. 
Залічваючы I. Яцкоўскага ў почат польскамоўных літаратараў Беларусі XIX стагоддзя, мы тым самым прызнаём ягоныя заслугі перад беларускаю культураю. А гэта азначае, што некалі ў новых энцыклапедыях з'явяцца папраўленыя і больш грунтойныя біяграмы; гісторыкі і літаратуразнаўцы дэталёва прааналізуюць творы паэта і пісьменніка, характарыстыка якіх будзе грунтавацца на мастацкіх вартасцях тэкстаў, а не на палітычнай ці нацыянальнай заангажаванасці аўтара.

На жаль, сёння не заўважаецца цікавасці беларускіх даследчыкаў да асобы і творчасці І. Яцкоўскага. Здавалася б, ужо сам факт, што у кнізе пісьменніка надрукаваны адметны беларускамоўны верш, павінен быў скіраваць навукойцай да грунтойнага вывучэння ягонае спадчыны. Аднак так не сталася. У раздзелах манаграфій і падручнікаў, прысвечаных Паўлюку Багрыму, звычайна знаходзілася месца толькі на некалькі радкой пра I. Яцкоўскага, запазычаных з артыкула Станіслава Сератвінскага у "Польскім слоўніку біяграфічным" 2. Не звярнуй увагу на I. Яцкойскага і I. Запрудскі ${ }^{3}$, аўтар фактычна першага сур'ёзнага даследавання праблемы атрыбуцыі верша "За́грай, за́грай, хло́пчэ ма́лы..." . Ён, напісаўшы у 1996 годзе, што ніякіх фактаў сувязі I. Яикойскага з беларускай літаратурай не ўстаноўлена, паўтарае гэтую думку і ў наступных публікацыях свае працы пра верш “За́грай, за́грай, хло́пчэ ма́лы..." - зборніках артыкулаў 2003 і 2012 гг. ${ }^{4}$ I гэта нягледзячы на тое, што цягам 2006-2010 гг. у друку з'явіўся шэраг матэрыялаў, у якіх ідзе гаворка якраз пра дачыненні эмігранта з Наваградчыны да мастацкай літаратуры. А таму незразумела: чаму I. Запрудскі анічога пра гэта не згадвае. Нібыта пасля сваіх публікацый

2 Гл.: S. Sierotwiński, Jackowski Ignacy, [w:] Polski stownik biograficzny, t. X/2, z. 45, Wrocław-Warszawa-Kraków 1963, s. 275-276.

3 Думаецца, I. Запрудскага "адштурхнула" ад І. Яцкоўскага тое, што Ёахім Лялевель назваў яго ӱ лісце да Валентыя Звяркоўскага ад 11.02.1853 г. "не дэмакратычным таварышам" (калі больш дакладна: Znam tylko "Panoramę" Jackowskiego o przepadtej przeszłości, ależ on nie demokracki towarzysz" (J. Lelewel, Listy emigracyjne, t. IV: 1849-1861, Wrocław-Kraków 1954, s. 142). Але тут Ё. Лялевель кажа у першую чаргу пра прыналежнасць I. Яцкойскага да г. зв. арыстакратычнай партыі Адама Чартарыскага. Рабіць выснову, што гэтая характарыстыла зусім не стасуецца з антыпрыгоннічкім пафасам верша, - няправільна. Ужо сам факт, што I. Яцкоўскі надрукаваў у сваёй кнізе "антыпрыгонніцкі" верш, сведчыць пра адваротнае. I у “Аповесці з майго часу...", і у карэспандэнцыі І. Яцкоўскага (Добра у нас кажуць: Служы Пану верне, то он табе пердне) знаходзім не адно пацвярджэнне гэтаму.

4 Гл.: І. Запрудскі, Нарысы гісторыі беларускай літаратуры ХІХ стагоддзя, Мінск 2003, с. 25; ён жа, Па дарозе на Парнас: Атрыбуцыйныля даследаванні $і$ пьтанні рэџэпџыі беларускай літаратуры ХІХ стагоддзя, Мінск 2012, с. 23. 
сярэдзіны 1990-х гадоў больш ніколі не звяртаўся да гэтае тэмы, не чытаў нічога на гэтую тэму. Ці, наадварот, свята верыць у сваю атрыбуцыю і нават не дапускае думкі, што можа быць інакш.

I зусім ужо прыкра, калі канцэпцыю І. Запрудскага бярэцца "абараняць" асоба, што ніколі не вывучала літаратурны працэс на Беларусі у XIX стагоддзі. Гаворка пра спробу Жаны Некрашэвіч-Кароткай аспрэчыць нашую нязгоду з прапанаванаю I. Запрудскім гіпотэзаю, што аўтарам верша “За́грай, за́грай, хло́пчэ ма́лы...” з'яўляецца Юльян Ляскоўскі. Вучонай (так звычайна Ж. Некрашэвіч-Кароткая называе сваіх апанентаў) не спадабалася, што мы ў адным з артыкулаў сцвердзілі: як сведчаџь даступныя сёння крынічь, эмігранты з Беларусі не мелі яшчэ самі ў той час пачуичя беларускае самасвядомасиі, а таму не магла ў іх нарадзічиа ідэя стварэння новай беларускай літаратурь з дапамогай падобнай містыфікаиылі ${ }^{5}$ ЖК. Некрашэвіч-Кароткая ўбачыла ў гэтым выказванні імкненне прасачыць эвалющыю абуджэння беларускай нацыянальнай свядомасці, а таму дазваляе сабе паіранізаваць: Здаециа, шанойны даследчык валодае чаройнай мензуркай або аптэкарскімі шалямі, якія дазваляюць яму вызначыць ступень беларускай самасвядомасиі ў той иі іншь перыяд часуб.

Застаецца толькі здзіўляцца: дзе гэта Ж. Некрашэвіч-Кароткая заўважыла у той нашай працы спробу прасачыць эвалющыю абуджэння нацыянальнай свядомасці? Гаворка там ішла толькі пра тое, што I. Яцкоўскі і А. Рыпінскі ${ }^{7}$, належачы да "партыі" Адама Чартарыскага, што асноўнай сваёй задачай бачыла адраджэнне Польшчы (не Рэчы Паспалітай абодвух народаў, а менавіта Польшчы), у сваіх шматлікіх публікацыях і прыватных лістах (апошніх захавалася некалькі сотняў) нідзе не згадваюць пра свае беларускія нацыянальныя сімпатыі. Дык

5 М. Хаўстовіч, Заграй, заграй, хлопчэ малью...: праблема аўтарства, [y:] Беларусіка=Albaruthenica 31: Новае слова ў беларусістыџы. Літаратуразнаўства i Фалькларыстыка: Матэрыяль V Міжнароднага кангрэса беларусістай, Мінск 2012, c. 257.

6 Ж. Некрашэвіч-Кароткая, Шматмоўная літаратура Беларусі ў кантэксце актуальньх літаратуразнаўчых канщэпџый: дапаможнік, Мінск 2015, с. 142.

7 Не згадваем тут Ю. Ляскоўскага, бо аніякіх фактаў пра ягоныя дачыненні з І. Яцкоўскім і А. Рыпінскім не захавалася. Больш за тое: прозвішча Ю. Ляскоўскага адсутнічае $\breve{y ~ с п і с а х ~ в ы г н а н ц а и ̆-~ " п а л я к а и ̆ ", ~ я к і м ~ а н г л і и ̆ с к і ~ у ̆ р а д ~ а к а з в а у ̆ ~ д а п а м о г у, ~}$ а г. зн. з І. Яцкойскім, што выплачваў гэтую дапамогу эмігрантам, магчымасці спаткацца былі чыста гіпатэтычныя (у Лондане ў той час знаходзіліся тысячы выхадцаў 3 былой Рэчы Паспалітай); а вось А. Рыпінскі жыў па-за Лонданам, які (па яго ўласных словах) ніколі не агледзеў (Рoеzije, Londyn 1853, s. 5). 
ці патрэбна тут нейкая чаройная мензурка? Няўжо не верыць дакументам эпохі?

Але найбольш істотнае тое, што Ж. Некрашэвіч-Кароткая ці то няўважліва чытала, ці то не зразумела прачытанае: у сваіх працах мы не аспрэчвалі прапанаваную навукойцам дату напісання верша “За́грай, за́грай, хло́пчэ ма́лы...". Якраз наадварот: як і І. Запрудскі, мы даводзілі, што вядомы беларускі верш узнік у 1840-я ці напачатку 1850-х гг., калі стваралася “Аповесць $з$ майго часу, альбо Літоўскія прыгоды".

I зусім ужо дылетанцкімі падаюцца развагі Ж. Некрашэвіч-Кароткай пра шаты народнай эстэтыкі. Маўляў, у беларускамоўных творах першае паловы XIX стагоддзя не стае народнай эстэтьюкі: пераважае або гумарыстычная $і$ сатырычна-парадыйная скіраванасць ("Энеіда навыварат" Вікениія Равінскага, "На прыезд Адама Мічкевіча" Яна Чачота, "Рабункі мужьикой" Яна Баршчэўскага), або занадта яўнь дыдактызм у спалучэнні з наўмысна спрошчанай паэтыкай ("Дзеванька", "Гарэліча" Яна Баршчэўскага)ㄱ․ Дзіӱнае сцвярджэнне: хіба, толькі той, хто не чытаў "Энеіды навыварат", адважыцца сказаць, што гэтай паэме не стае народнай эстэтылкі.

Піша ж гэта Ж. Некрашэвіч-Кароткая дзеля таго, каб давесці, што зусім слушна В. Дунін-Марцінкевіч, не ведаючы верша “За́грай, за́грай, хло́пчэ ма́лы..." (дзе, відавочна, народнае эстэтыкі дастаткова), з гонарам заявіў у прысвячэнні Аляксандру Лапе, змешчаным напачатку зборніка "Ciekawyś? - Przeczytaj!” (у Ж. Некрашэвіч-Кароткай - у прадмове да вершаванае аповесці "Купала"): Няхай што хочуць гавораџь, але ж гэта я першы паэзію нашага сялянскага люду апрануў у шаты народнай эстэтыкі, увёў на сцэну жьиия $i$ пакінуў у шэрагу творай айчыннага пісьменства, чым $i$ ганаруся ${ }^{9}$. Маўляў, В. Дунін-Марцінкевіч усведамляў сваю ролю як пачынальніка беларускае літаратуры і ганарыйся не тылм, што пісаў па-беларуску: «апрануць» паэзію «ў шаты народнай эстэтыкі» - намнога больш важная задача $\partial л я я$ яго як для твориьи ${ }^{10}$ А г. зн., усё савецкае літаратуразнаўства памылялася, калі лічыла пачынальнікамі новай беларускай літаратуры тых, хто пісай у першай палове XIX стагоддзя па-беларуску.

\footnotetext{
8 Ж. Некрашэвіч-Кароткая, Шматмоўная літаратура Беларусі ў кантэксце актуальньх літаратуразнаўчых канџэпџый: дапаможнік, с. 143.

9 Тамсама.

10 Тамсама.
} 
Аднак анічога падобнага В. Дунін-Марцінкевіч не сцвярджаў і аніякую паэзію не апранаў у шать народнай эстэтыкі. Колішняя па-

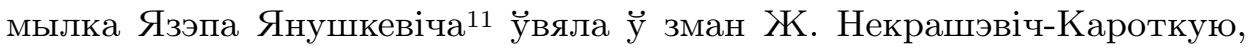
якая стварыла недарэчную і дзіўную тэорыю-абгрунтаванне, што рэзка адрозны у сваёй мастачкай дасканаласиі верш "Зайграй, зайграй, хлопча малы..." выляўляе усёй сваёй паэтыцнай фактурай слушнасць меркавання I. Запрудскага, які пераканаўча даказаў, што гэты верш не мог быиь напісань раней, як у 50-х гг. XIX ст." ${ }^{12}$.

Вельмі добра ведаць актуальныя літаратуразнаўчыя канцэпцыі, але калі пішаш даследаванне па гісторыі літаратуры, то найперш трэба ведаць літаратурны працэс, тыя абставіны, у якіх ён адбываўся, і той "архіўны пыл", што данёс да нашага часу сведчанні абуджэння начьянальнае свядомасиі беларускага народа.

Не раз імя I. Яцкоўскага як аўтара верша "За́грай, за́грай, хло́пчэ ма́лы..." згадваў у сваіх публікацыях баранавіцкі краязнаўца Міхась Маліноўскі ${ }^{13}$. Але яго манера выкладання сваіх, звычайна без аргументай, домыслай і фантазій, хоць не пазбайленых часам рацыянальнага (як ні дзіўна!) зярняці, не дазваляе ўключаць напісанае ім у навуковы дыскурс.

На жаль, асобныя беларускія літаратуразнаўцы, палемізуючы з выказваннямі (часта літаральна абразлівымі) М. Маліноўскага, не здолелі вылучыць з недакладнасцяй ды інсінуацый краязнаўца тыя ягоныя здагадкі і меркаванні, якія могуць прывесці да выяўлення ісціны. Так, Г. Кісялёў у навуковай экспертызе кнігі М. Маліноўскага "Павел Іосіфавіч Багрым (Паўлюк Багрым): Легенды, праўда, загадкі" (Баранавічы 2006), зацверджанай Інстытутам літаратуры НАН Беларусі, напісаў: Бяздоказныля $і$ безадказньяя навацьі М.М. Маліноўскага

\footnotetext{
11 У арыгінале чытаем: Niechaj co chca mówia - ja przecież piérwszy poezye naszego wieśniaczego ludu przywdziałem w szate rodowej estetyki (вылучэнне нашае - M. X.), $w$ wiodtem na scene życia $i$ postawitem $w$ szeregach utworów piśmiennictwa rodowego (вылучэнне нашае - M. X.), z czego się chlubię (W. Dunin-Marcinkiewicz, Ciekawyś? - Przeczytaj! Trzy powiastki i wierszyk ulotny, Mińsk 1856, s. n. n.) Шаты rodowej estetyki В. Дуніна-Марцінкевіча азначаюць нічога іншага, а толькі шаты айчыннай, г. зн. польскай (рэчыпаспалітаўскай) літаратуры!

12 Ж. Некрашэвіч-Кароткая, Шматмоўная літаратура Беларусі ў кантэксие актуальных літаратуразнаўчых канџэпџый: дапаможнік, с. 143.

13 Звычайна, з негатыўнай канатацыяй: "польскі масон", "нацыянал-шавініст", "русафоб". Відавочна, з гэтай прычыны (верш "За́грай, за́грай, хло́пчэ ма́лы..." належыць пяру І. Яцкоўскага) М. Маліноўскі стараўся выкасаваць верш са школьнае праграмы, каб пасля з гонарам заявіць: Усё-ткі я дамогся выключэння жыция $i$ «вворчасиі» Багрыма са школьных праграм.
} 
не могущь быць прыняты $i$ ўхваленыл. Ганаровае месиа сялянскага самародка Багрьма ў айчьннай гісторьі застаечиа непарушанылм ${ }^{14}$. Праўда, крыху пазней, пазнаёміӱшыся з нашымі публікацыямі на тэму атрыбуцыі аўтарства верша “За́грай, за́грай, хло́пчэ ма́лы...”, вядомы гісторык літаратуры ў інтэрв'ю Беларускай праграме Польскага радыё 19 мая 2007 года крыху змяніӱ сваё меркаванне: [Кісялёў:] Мінулае, калі абрастае дадатковьмі дэталямі, можа рабіџиа яшчэ больш прыгожыл. [Карэспандэнт:] A што вы скажаче наконт вэрсіі Ігната Яикоўскага, як ауттара верша, што прыпісваеица Паўлюку Багрьлм? [Кісялёу:] Ёсьиь такая вэрсія. Але гэта толькі меркаваньне, яшчэ далёкае да таго, каб мь яго прьзналі. Калі Ячкоўскі, дык мь атрылліваем яшчэ аднаго беларускага пісьменьніка. У рэшие рэшт нас иікавіць толькі ісьиіна ${ }^{15}$.

Сёння абараняць міф пра першага сялянскага паэта, на нашу думку, ужо недаравальна. Гэта азначае проста заплюшчыць вочы і на уввдзеныя $\ddot{y}$ навуковы узжытак новыя матэрыялы, і на логіку развіцця падзей у Крашыне ў 1828 годзе. Тым не менш, нават такі абазнаны ў гісторыі айчыннай літаратуры XIX стагоддзя даследчык як Я. Янушкевіч працягвае адстойваць даўні сацыялістычна-савецкі міф. Пошукі ісціны ён называе спробамі апошняга часу адабраџь ад П. Багрьлма аўтарства верша, дасланыя ксяндзом Каралем Жураўскім на адрас Акадэміі навук Беларусі ў 1988 годзе фотакопіi чатырох дакументай пра сям'ю П. Багрыма лічыць унікальнымі, але падае iх у перакладзе - да сённяшняга дня мы не маем іх навуковай публікацыі ${ }^{16}$. Самае прыкрае тое, што Я. Янушкевіч стаў на шлях абразлівага трактавання апанентаў (відавочна, запазычыўшы прыёмы баранавіцкага краязнаўца): Некаторья аматарь ад краязнаўства $і$ ад навукі акадэмічнай палічьлі за лепшае засумнявациа ў аўтарстве верша, адмаўляючь яго на карьсць першапублікатара Яикоўскага (згодна выслоўю: сумнявайся, каб і іншыля палічьлі, што ты нешта ведаеш)17.

14 Л. Кісялёва, 3 архіва Генадзя Кісялёва, [у:] "Пачуць як лёсу валяциа мурь": Памяиі Генадзя Кісялёва, Мінск 2009, с. 48.

15 Г. Гарачка, Загадкі й таямніиь роднай літаратурь, [online], http://www2.pol skieradio.pl/eo/dokument.aspx?iid=52659 [доступ: 06.01.2017].

16 у "кнізе-буклеце" (sic!) "А у маскалях трудна жыці..." Я. Янушкевіч падае фотакопіі К. Жураўскага, але змяншаючы іх так (8x10,5 ператвараюцца у яго ў 3x4), каб немагчыма было прачытаць.

17 Я. Янушкевіч, “А уั маскалях трудна жьці...”: Багрым-Крашын-Яикойскі-неўміручасць: Да 200-годзьдзя Паўлюка Багрыма і 570-годзьдзя Крашына, Ракаў 2012, c. 4 . 
А вось унікальнасць апублікаваных (хутчэй: пераказаных) дакументаў даследчыкам яўна перабольшваецца: аніводным з іх не можа быць пацверджанае аўтарства “За́грай, за́грай, хло́пчэ ма́лы...”. Якраз наадварот: менавіта, веданне даты нараджэння і даты шлюбу П. Багрыма, а таксама даты смерці Юзафа Багрыма дазволіла засумнявацца ў аўтарстве. Сам таго не жадаючы, Я. Янушкевіч спрычыніўся да таго, што спачатку М. Маліноўскі, а пасля і "прафесійныя знаўцы" прапанавалі свае гіпотэзы атрыбуцыі верша XIX стагоддзя.

Паказальна, што беларускія літаратуразнаўцы не аспрэчылі ні гіпотэзу I. Запрудскага (на месца сялянскага падлетка Паўлюка Багрылма (...) прапанавачь шарачковага шляхиіча Юльяна Ляскоўскага), ні нашую гіпотэзу (найбольш верагодным аўтарам верша "За́грай, за́грай, хло́пчэ ма́лы...” з'яўляецца І. Яцкоўскі). Бо, апрача “кнігі-буклета" Я. Янушкевіча, нам вядомы толькі артыкул светлай памяці Генадзя Праневіча "ПАн ТАдэвуш Адама Міцкевіча і АПовесць 3 МАйГО ЧАСУ, АЛЬБО ЛІтойскія ПРЫГОДы Ігната Яцкоўскага", у якім нам бачыцца спроба і рэанімаваць даўні міф пра П. Багрыма, і абараніць уласную публікацыю пра крашынскага паэта з палемічнымі выпадамі супраць выказванняў М. Маліноўскага, надрукаваную яшчэ у 1994 годзе ${ }^{18}$.

На залежнасць твора I. Яцкоўскага ад славутае паэмы А. Міцкевіча звярталі ӱвагу яшчэ сучаснікі-эмігранты (напрыклад, Адам Міхалойскі $^{19}$ ), а пазней - Уладзіслаў Каратынскі ${ }^{20}$, Станіслай Пігань ${ }^{21}$, Леанард Падгорскі-Аколай ${ }^{22}$, Збігнеў Судольскі ${ }^{23}$. Праўда, даволі дзіўна, што Г. Праневіч не палічыў патрэбным згадаць папярэднікаў і прааналізаваныя імі матывы тэкстаў абодвух выхадцаў наваградскае зямлі. Ягоныя ж уласныя назіранні часта можна назваць адно гіпатэтычнымі: I. Яикойскаму, які паслаў земляку сваю кнігу, вельмі хачелася не толькі аспрэчыць $і$ ўдакладнічь иі дапойнічь некаторыя факть i дэталі "Пана Тадэвуша", але $i$ данесиі да А. Мічкевіча трагедыю

\footnotetext{
18 Гл.: Г. Праневіч, Храм Багрылмавага верша, [у:] Паўлюк Багрыл, Мінск 1994, c. $141-149$.

19 Гл.: A. Michałowski, Trzyletni pobyt na Wschodzie, Londyn 1857, s. 250-254.

20 Гл.: Wł. Korotyński, "Powieść z czasu mojego": Studium Lterackie, "Kraj", t. XXV, Petersburg 1895, nr 17, s. 15.

21 Гл.: S. Pigoń, Pan Tadeusz. Wzrost, wielkość i stawa, Kraków 2002, s. 30, 44-45.

22 Гл.: L. Podhorski-Okołów, Realia Mickiewiczowskie, Warszawa 1999, s. 381.

23 Гл.: Z. Sudolski, Pan Tadeusz $w$ romans przemieniony, czyli Powieść czasu mojego, [w:] Pan Tadeusz i jego dziedzictwo: recepcja, red. B. Dopart, Kraków 2006, s. 33-53.
} 
таленавітага беларускага хлопчыка, трагедыю яго незрэалізаванага ва уัмовах жорсткага иарскага прымусу таленту 24. Усё ж "трагедыя" Пётрака (сам I. Яцкоўскі выказаўся больш дакладна: "няшчасця") падаецца ў кнізе літаральна некалькімі абзацамі, а, думаецца, каб пісьменнік хацеў “данесці" гісторыю паэта П. Багрыма, то ён прысвяціў бы яму значна больш месца.

Што датычыць аргументаў, якімі Г. Праневіч імкнецца выразіць нязгоду з нашай гіпотэзай, дык яны зной жа чыста гіпатэтычныя: Не мог паэт сярэдняй рукі, якім бый I. Ячкойскі, праз 20 гадой пасля падзеі (а з верша выразна відаџь, што напісань ён падлеткам, непасрэдным сведкам трагедыі, а не пажыльм, стальм чалавекам, якім быў на тую пару I. Ячкоўскі) раптам напісаць геніяльны твор 25. Прычым, сваю выснову пра паэтычны талент эмігранта Г. Праневіч "засноўвае" на нібыта нашай ацэнцы ягонае творчасці, прыпісваючы нам "негатыўна-крытычнае" стаўленне да яе. На жаль, асобнік "Тэрмапілаў" трапіў да нас ужо тады, калі Г. Праневіча не было у жывых, а таму задаць пытанне: "дзе гэта і як у нашых публікацыях выявілася "негатыўна-крытычная" ацэнка польскамоўнае паэзіі I. Яцкоўскага?" было немагчыма.

Аргументаў, якімі мы абгрунтойвалі сваю гіпотэзу, Г. Праневічу было яўна недастаткова. Праўда, ён ведаў толькі адну нашую публікацыю ("Я, хоць і не паэта...", “Arche" 2008, № 7-8, с. 880-923), аднак мы разумеем: як усе ранейшыя нашыя аргументы на карысць I. Яцкойскага, так і новыя, пададзеныя ў гэтым артыкуле, не могуць канчаткова паставіць усе кропкі над "i".

Перш-наперш лічым патрэбным сказаць, што мы не ведаем дакладна, хто напісаў верш “За́грай, за́грай, хло́пчэ малы́...”. Але, на нашу думку, Паўлюку (Паўлу) Багрыму твор прыпісваецца беспадстаўна. На сённяшні дзень даследчыкі не выявілі аніводнага дакумента, які б сведчыў пра датычнасць П. Багрыма да славутага верша. Фактычна, Аўгусцінас Янулайціс (1878-1950) у 1913 годзе на падставе ўскосных сведчанняй стварыў легенду. Прычым так, што пазнейшыя даследчыкі нават не "заўважылі" гэтага. Літоўскі гісторык, даведаўшыся пра публікацыю Вацлавам Ластоўскім у "Нашай Ніве"

24 Г. Праневіч, ПАн ТАДэвУШ Адама Мічкевіча $і$ АПовеСЦь з мАйГо чАСу, АЛЬБО ЛІтоУСКІя прыгоды Іаната Ячкоўскага, “Тэрмапілы” 2016, № 20, с. 252.

25 Тамсама, с. 266. 
перакладу-пераказу 26 XXIX раздзела "Працяг. Ксёндз Магнушэўскі. Юрага. Паэт Пётрак" кнігі I. Яцкойскага "Аповесць з майго часу, або Літоўскія прыгоды", параўнаў яго з вядомымі яму архіўнымі матэрыяламі пра сялянскі бунт у 1820-я гады ў мястэчку Крашын і давёў, што прататыпам паэта Пётрака з кнігі I. Яцкоўскага з'яўляецца рэальная асоба - Павел Багрым. Адначасна ён нідзе наўпрост не сцвярджае, што верш “За́грай, за́грай...” напісай П. Багрым. I. Запрудскі, які быў адным з першых, хто звярнуй увагу на патрэбу навуковага падыходу да "зацверджанай" савецкай ідэалогіяй легенды, палічыў нават, што А. Янулайчіс не назваў П. Багрыма ауттарам верша "Зайграй...", бо наяўныя дакументь падстаў для гэтага відавочна не давалі27. Аднак гэта не зусім так. Па-першае, свой артыкул А. Янулайціс назваў "Аб маладым паэце з Крошына", відавочна маючы на ўвазе не толькі Пётрака, а менавіта Пётрака і Паўла Багрыма ў адной іпастасі. Па-другое, у артыкуле ён піша:

Хлопчыкі пачынаюць пісаць вершы, яны то стараюцца пісаць на спадобу тых арыгіналаў, што чыталі, то зноў пробуюць напісаць сваё, беручы тое, што яны самі чулі і бачылі. 3 ліку гэткіх хлопчыкаў вядомы нам толькі адзін, Павел Багрым. Будучы ў школе, ён вельмі любіў пісаць вершы. Многа вершаў з Нарушэвіча, баек Эзопа і інш. умеў ён на памяць; перапісваў, што пападалася, не толькі друкаванае, але і рукапіснае. (Вершы і песні пападалі у Крошын рознымі шляхамі. Адны браліся 3 кніг, другія хадзілі ӱ рукапісных запісах; гэтак было з вершам Размова мужыкой ${ }^{28}$. Яго, пачынаючага думаць, душыла цяжкая мужыцкая доля, і гарэлі вочкі, калі перапісваў словы і вершы аб мужыцкай свабодзе. (...) У аднаго з вучняў, Багрыма, знайшлі вершы, якія паказаліся падазронымі. (...) Кс. Магнушэўскі стаў хваліць Паўла Багрыма, што ён болей вершаў ведае на памяць, а не толькі тыя, што ў яго ўзялі 29 .

На жаль, у дадзеным фрагменце пераважаюць здагадкі і фантазія гісторыка, бо ні ў І. Яцкойскага, ні ў архіӱных крыніцах мы не сустракаем інфармацыі пра тое, што: 1. хлопчыкі школы кс. Магнушэўскага

26 Гл.: Пятрок з Крошына, "Наша Ніва" 1911, № 30 (28 ліпеня). У версіі грамадзянскім шрыфтам артыкул надрукаваны без подпісу аўтара, беларускаю лацінкаю падпісаны - Wlast.

27 І. Запрудскі, Пьътанні атрыбуцьі, паэтыка $і$ эстэтыюа верша ЗАйГРАй, ЗАйГРАй ХлопчА малы..., [у:] І. Запру дскі, Нарысы гісторыі беларускай літаратуры XIX стагоддзя, Мінск 2003, с. 11.

28 Тэкст, пададзены ў нас у дужках, змешчаны ў А. Янулайціса ў зносцы.

29 А. Янулайціс, Аб маладым паэце з Крошына, "Маладая Беларусь" 1913, сер. I, сш. 3, с. 11-14. 
пісалі вершы; 2. што П. Багрым вучыўся ў школцы; 3. што П. Багрыма "душыла цяжкая мужыцкая доля" (быў ён мешчанінам і слугою ксяндза В. Магнушэўскага); 4. што знайшлі ̈ П. Багрыма вершы (насамрэч, ён прачытаў па сваёй ініцыятыве "Rozmowu Chłopow", бо кс. Магнушэўскі прасіў дэкламаваць розныяя байкі, а той прастадушна расказаў на памячь $i$ гэтьия вершыз ${ }^{30}$, а пасля перапісаў твор Я. Баршчэўскага па загаду чыноўніка); 5. што кс. Магнушэўскі хваліў П. Багрыма пасля таго, як у хлапчука ўжо "ўзялі" нейкія вершы.

Аднак на дадзеныя неадпаведнасці ніхто 3 літаратуразнаўцаў і гісторыкаў не звяртаў увагі. Відаць, больш істотным было тое, што створаны А. Янулайцісам вобраз "сялянскага паэта" адпавядаў сацыялістычнай ідэалогіi прадстаўнікой беларускага нацыянальнага руху (таксама і пазнейшай камуністычнай уладзе на Беларусі). М. Гарэцкі у 1920 годзе коратка пераказаў артыкул з "Маладой Беларусі" у сваім падручніку "Гісторыя беларускае літэратуры" 31, а таксама даў кароткую характарыстыку “твораў” П. Багрыма: верша "За́грай, за́грай...", "Гутаркі Данілы са Сцяпанам" ды "Размовы пана 3 мужыком". Хто "ініцыяваў" павялічэнне творчага даробку П. Багрыма? М. Гарэцкі спаслаўся на няпэўнае “кажуць", а вось Я. Карскі ${ }^{32}$, які у сваёй працы, выдадзенай у 1922 годзе, таксама даў адмысловы, хоць і невялікі, раздзел "Павел Багрым", выкарыстоўвае "сведения" Р. Зямкевіча ${ }^{33}$.

30 Пачьънальнікі: 3 гісторыка-літаратурных матэрыллаў ХІХ ст., уклад. Г. Кісялёў, Мінск 1977, с. 202.

31 М. Гарэцкі, Гісторыя беларускае літэратуры, Вільня 1920, с. 59-62.

32 Нам не уддалося пазнаёміцца з усімі публікацыямі Я. Карскага па гісторыі беларускае літаратуры, якія ён змяшчаў у газеце "Беларусь". Перадусім, цікавасць выклікае № 7 выдання (за 13 студзеня 1920 г.), дзе друкаваўся працяг артыкула "Беларускія творы Вінцэся Каратынскага" з № 4 газеты, бо менавіта напрыканцы яго маглі быць раздзелы "Г. Арцымоўскі і Павел Багрым".

33 Е. Карский, Белорусы, в 3 т., т. 3, кн. 2: Очерки словестности белорусского племени, Минск 2007, с. 301-302. Цікава, што Р. Зямкевіч у 1915 г. жыў у Крашыне, парадкуючы бібліятэку К. Святаполк-Завадскага. Гл.: В. Лабачэўская, Фалькларыстычны архіў Беларускага музея імя Івана Лучкевіча: Вяртанне праз 65 гадоў, [у:] "Ноmo Historicus 2012: Гадавік антрапалагічнай гісторы”" 2012, с. 473-474, 484, 486. Як пацвярджэнне - нататка R. Sunicy ў газеце "Biełarus": Piszuć da nas. M-ko Kroszyn, Nawahrudzkaho pawietu. Miasteczka naszaje ǔsio katalickaje. Majem piekny kaściol, pastaŭleny wiadomym ksiandzam Magnuszeǔskim, jaki u 1826 hadu szmat dobraho zrabiǔ dla naszych mieszczan, katorych chacieli zapisać da sielan. Pamiać biełaruskaho paeta Paŭła Bochryma dahetul żywieć pamiż nami. Dzie chto i umiejeć jaho wierszy "Zahraj, zahraj, chłopcze mały" na pamiać. 24 maja byǔ u nas kiermasz dy pracessija Bożaho Cieła. Naszyja mieszczania zrabili kolki pieknych aŭtaroŭ u miasteczku. Гл.: "Biełarus" 1915, № 21-22 (4 czerwienia). 
Істотным для легенды было і тое, што М. Гарэцкі "пераіменаваў" Паўла Багрыма ў Паўлюка. Такое адметнае гучанне імя героя легенды спрыяла пашырэнню гісторыі пра таленавітага падлетка, талент якога загубілі паны-прыгоннікі і царызм, хоць асноўным, вядома, было нібыта сялянскае паходжанне П. Багрыма. А таму ён - першы беларускі сялянскі паэт. Менавіта, "сялянскі", а не "шляхецкі" і “польскі", як амаль усе іншыя літаратары Беларусі XIX стагоддзя. Гэтая акалічнасць замацавала $\ddot{\mathrm{y}}$ свядомасці як чытачоў, так і літаратуразнаўцай дадзеную легенду, што цягам усяго савецкага перыяду непахісна дамінавала: на варце сялянскага паэта стаяла ўся ідэалагічная машына камуністычнага ладу.

Паказальна, што адразу пасля краху савецкай дзяржаўнасці і камуністычнай ідэалогіі з'явілася і першая крытыка легенды: у 1992 годзе краязнаўца М. Маліноўскі выступіӱ у друку з артыкулам пад характэрным тытулам "Ці быў Паўлюк Багрым паэтам?" 34. Гэта быў зухаваты выпад ваяўнічага дылетантызму ${ }^{35}$, але ён прымусіў навукойцаў больш пільна прыгледзецца да праблемы атрыбуцыі верша. У выніку ўзнікла першае грунтойнае даследаванне ${ }^{36}$, у якім былі акрэслены задачы як вывучэння праблемы аўтарства хрэстаматыйнага твора, так і літаратурнае спадчыны Беларусі XIX стагоддзя ўвогуле. У другой частцы даследавання I. Запрудскі паспрабаваў вырашыць пытанне атрыбуцыі верша “За́грай, за́грай...”. Ён справядліва звярнуў увагу на лонданскую друкарню-выдавецтва А. Рыпінскага і кампаніi, дзе ў 1854 годзе ўбачыў свет згаданы верш. Праўда, не маючы доступу да архіўных і іншых матэрыялаў, I. Запрудскі пайшоў шляхам "канструявання таго, што магло быць", на падставе ўскосных сведчанняў. Ягоная гіпотэза (аўтарам верша прапанавалася лічыць Ю. Ляскоўскага ${ }^{37}$ ) падавалася цікаваю, але на яе карысць не было пададзена аніякіх аргументаў толькі домыслы-дапушчэнні.

34 М. Маліноўскі, Ці быз Паўлюк Багрым паэтам?, "Во славу Родины" 1992, 9 сент.

35 Пачынаючы з 1992 г., М. Маліноўскі надрукаваў некалькі дзясяткаў артыкулаў і кнігу Павел Іосіфавіч Багрым (Пайлюк Багрым): Легенды, праўда, загадкі (Баранавічы 2006, 128 с.), у якіх мэтанакіравана імкнуўся дыскрэдытаваць асобу П. Багрыма, прыпісаць яму ролю правакатара ӱ крашынскіх падзеях 1828 г.

36 Гл.: І. Запрудскі, Скажыие, хто Вы?!: Літаратуразнаўчыя абразкі, "Першацвет" 1996, № 2, с. 112-130.

37 Гл.: I. Запрудскі, У пошуках alter ego: Да 170-годдзя з дня нараджэння Юльяна Ляскойскага, "Першацвет" 1996, № 7, с. 88-109. 
На нашу думку, найбольш верагодным аўтарам верша "За́грай, за́грай..." трэба лічыць Ігнацы Яцкоўскага. Незвычайнасць гэтае гіпотэзы $\ddot{y}$ тым, што даследчыку, які адважыцца яе распрацойваць, давядзецца аспрэчваць самога I. Яцкоўскага, які нібыта выразна засведчыў, што пра крашынскія падзеі у ягонай кнізе апавядаецца бесстароннім назіральнікам, а г. зн. максімальна праўдзіва. Тым не менш, варта паспрачацца $з$ аўтарам, які мог мець свае прычыны выдаваць уяўнае за рэальнае.

Што варта браць пад увагу, аналізуючы архіӱныя матэрыялы, літаратурныя крыніцы і навуковыя даследаванні, так ці інакш датычныя праблемы атрыбуцы верша “За́грай, за́грай...”? Мы можам вылучыць наступнае:

\section{1. Мастацкі характар кнігі I. Яцкойскага “Аповесць з майго часу, або Літоўскія прыгоды".}

Той, хто прачытаў твор цалкам, пагодзіцца са сцвярджэннем, што кніга I. Яцкоўскага - гэта аповесць, а не ўспаміны. Больш складана здагадацца, што адной з ідэй гэтага мастацкага тэксту з'яўляецца жаданне аспрэчыць "Пана Тадэвуша" А. Міцкевіча, а г. зн. рамантычнае ўспрыняцце падзей "французскае” вайны, якая вялася аніяк не у інтарэсах Рэчы Паспалітае. Падобная інтэрпрэтацыя гісторыі выразна выяўляецца ў вершы паэта "Панарама", што папярэднічаў напісанню "Аповесці...". Але не менш важная ідэя, якую імкнуўся давесці свайму чытачу аўтар, - гэта і думка пра жорсткі і несправядлівы лад, які ўсталяваўся на Бацькайшчыне цягам апошніх дзесяцігоддзяй, лад, які з'яўляецца акупацыйным і варожым не толькі для шляхты, але і для сялян. Невыпадкова, думаецца, з'яўляюцца напрыканцы раздзела пра паэта Пётрака наступныя словы: Бёрнс, парабак англійскі, пры менш ияжкіх акалічнасиях, уласньм талентам, без усялякае навукі, забяспечьў сабе неўміручае імя, а сваёи сям'i - пашану і дастатак; Пётрак з Крашына за талент, дадзены яму Богам, зазнаў самае жорсткае няшчасце! ${ }^{13}$. На наш погляд, менавіта вядомая I. Яцкоўскаму гісторыя Роберта Бёрнса стала падставаю (ройна як і гісторыя пра следства ў Крашыне над хлапчуком, які перад чыноўнікам przeczytat poezie wlasne w ruskim narzeczu) дзеля стварэння гісторыі паэта Пётрака, якая $\ddot{\mathrm{y}}$ XX стагоддзі ператварылася ў легенду Паўлюка Багрыма.

38 І. Яцкойскі, Аповесиь майго часу, альбо Літойскія прыгоды, Варшава 2010, c. 181 . 


\section{2. Літаратурныя здольнасці І. Яцкоўскага.}

Ніякіх сумневаў тут быць не можа: корпус апублікаваных і рукапісных тэкстаў даводзіць, што I. Яцкоўскі валодай літаратурным талентам. Першыя згадкі пра гэта (датаваныя 1834 г.) знаходзім у нататніках Л. Нядзвецкага ${ }^{39}$, а таксама ва "Успамінах..." Яна Барткоўскага 40 : I. Яцкоўскі ў коле эмігрантаў часта займальна апавядаў "шляхецкія" гісторыі, якія прысутныя называлі "каментаром" да "Успамінаў Сапліцы" Генрыка Жавускага. Пазней І. Яцкоўскі дасылае вершаваныя творы Л. Нядзвецкаму ў Парыж, прызначаючы асобныя для друку. Яны прасякнуты характэрным для гэтага творцы патрыятызмам, які грунтаваўся на любові да малое Айчыны - Літвы-Наваградчыны і быў адначасна выяўленнем дзяржаўнага пачуцця да Рэчы Паспалітае. Яшчэ больш яскрава дадзеная тэндэнцыйнасць ягонай творчасці выступіла у у празаічнай "Аповесці з майго часу, альбо Літоўскіх прыгодах".

Л. Нядзвецкі яшчэ з 30-х гг. быў знаёмы з "літаратурнымі планамі" I. Яцкоўскага і, больш за тое, можа лічыцца адным з тых, хто заахвоціў напісаць твор. Ідэя напісання "Аповесці...", відавочна, нарадзілася пад уплывам кнігі Г. Жавускага "Успаміны Сапліцы", якую I. Яцкоўскі атрымаў з дапамогай Л. Нядзвецкага яшчэ у 1839 годзе: Яму дашлі асобнік Pamiętnik[a] pana Soplicy. Ён дадумваециа, иі не напісаў іx старь Чачот, чалавек вельмі прыстойнь, што маючь мала, уласнаю прачаю дабіўся заможнасчі і сёння ўжо ў гадах. Саплічу аднаго сабе згадвае, але вялікага дурня ${ }^{41}$.

Літаратурная актыўнасць I. Яцкойскага ў першай палове 1850-х гадоў звязана з дзейнасцю друкарні-выдавецтва А. Рыпінскага ў Лондане. Не выключаем, што поспех беларускамоўнае балады А. Рыпінскага "Нячысцік", якую з-за цікавасці да яе сярод эмігрантаў лонданская друкарня выдала тройчы (двойчы асобнымі брашуркамі), падахвоціў I. Яцкоўскага напісаць яшчэ адзін раздзел кнігі (XXIX), для якога, не памятаючы, а хутчэй не ведаючы верша, які чытаў перад следчымі П. Багрым, стварыў уласны - “За́грай, за́грай, хло́пчэ ма́лы...", - а таксама ягоны пераклад на польскую мову. Дваццаць

\footnotetext{
39 L. Niedźwiecki, Naszych gromadek gadułki, [w:] Rps Kórn, sygn. 2414: L. Niedźwiecki, Materiaty do dziennika z okresu pobytu w Anglii w latach 1831-1839, s. 72-74.

40 J. Bartkowski, Wspomnienia z powstania 1831 roku i pierwszych lat emigracji, oprac. E. Sawrymowicz, Kraków 1967, s. 262.

41 L. Niedźwiecki, Listy wybrane z lat 1832-1839, oprac. St. Makowski, Warszawa 2009, s. 580.
} 
дзевяць радкоў вядомага беларускамоўнага верша $\ddot{y}$ ідэйна-стылістычных і нават лексічных адносінах цалкам адпавядаюць паэтыцы польскамоўных твораў І. Яцкойскага. Яго версіфікатарскі вопыт - а гэта 1013 вершаваных радкой, 864 з якіх былі надрукаваны (361 ананімна) і 477 з якіх напісаны харэем - таксама можа сведчыць пра паэта як пра аўтара верша “За́грай, за́грай...”.

\section{3. Выкарыстанне ў творах I. Яцкойскага характэрных выра- зай з верша "За́грай, за́грай...".}

У сваіх публікацыя пра жыццёвы і творчы шлях І. Яцкоўскага мы ўжо звярталі ӱвагу, што даволі характэрны выраз верша "За́грай, за́грай..." Hdzie|z ja biedny abiarnusia? сустракаецца ў тэкстах, якія без усякіх сумневаў належаць самому пісьменніку. Так, у вершы "Do S. Koźmiana i T. Olizarowskiego" (1849) у 11-й страфе мы чытаем:

Potyrawszy w pielgrzymce me lata i siły,

Sobiem ciężar, i innym gość wcale niemiły,

Gdzie $\mid \dot{z}$ się biedny obrócę, włóczęga wiekowy?

Przed grobem, ja nie znajdę spoczynku dla głowy.

У “Аповесці з майго часу, ці Літойскіх прыгодах" дадзены выраз ужыты ажно тройчы: у IV раздзеле, калі ахмістрыня панства Войскіх Кукевічова, пачуўшы, што ёй павышаюць jurgielt (плату за службу), роспачна Ч̆скрыквае: - Ach! Moja Imość (...) pierwszy raz przede mna straszna otwarta sie przyszłość. Tam gdzie jest jurgielt, tam jest $i$ odprawa, a gdzie $\mid \dot{z}$ się ja biedna obrócę, kiedy się podoba Ichmościom oddalić mie od siebie?, а таксама двойчы ў раздзеле XXIX, у вершы “За́грай, за́грай, хло́пчэ ма́лы..." па-беларуску:

Mnie pastuszkom wiek niabyci,

A ŭ Maskalach trudna życi,

A ja i raści bajusia,

Hdzie $\mid \dot{z}$ ja biedny abiarnusia?

і ў польскім перакладзе:

Wieku z trzodą nie przepędzę,

A zaś w wojsku widzę nędzę;

Ja gdy rosnę, to się smucę,

Bo gdzie|ż biedny się obrócę?

Польскае obrócić się азначае сярод іншага і 'пайсці, накіравацца y̆ нейкі бок'. "Słownik języka polskiego" падае з Генрыка Сянкевіча наступны прыклад: Ludzie, obłakani z przestrachu, wypadali z namiotów nie 
wiedzac, gdzie się obrócić, w która stronę uciekać42. Відавочна, у дадзеным кантэксце гэты выраз азначае 'дзе дзецца?' Беларускія слоўнікі не фіксуюць падобнага значэння, а тлумачэнне 'змяніцца, ператварыцца ў новую якасць. У казках - ператварыцца ў каго-н., што-н. пры дапамозе чараў', як падае “Тлумачальны слойнік беларускай мовы” ${ }^{43}$, цалкам адпавядаючы словам з трэцяе страфы верша $W$ Waŭkałaka abiarnusia, // Z szczaściam na was abzirnusia, не пакрывае тое сэнсавае поле, якое мае выраз Hdzie|ż ja biedny abiarnusia? з шостае страфы хрэстаматыйнага беларускага твора. Відавочна, паэт “запазычвае" дадзенае значэнне слова 'абярнуся' з польскае мовы. Заўважым: у даўняй польскай мове дадзены выраз сустракаўся даволі часта.

Можа, І. Яцкоўскі проста ўжыў у сваіх творах радок з верша Пётрака з Крашына (П. Багрыма)? Але больш праўдападобна, што польскае значэнне выразу Hdzie $\dot{z}$ ja biedny abiarnusia? узнікла у беларускамоўным тэксце пад уплывам польскае мовы аўтара - I. Яцкойскага. Трэба ўлічваць і тое, што сам пісьменнік не раз у сваёй туляцкай адысеі павінен быў задацца пытаннем $\boldsymbol{a}$ gdzie $\mid \dot{z}$ się ja biedny obrócę?

Асобнае пытанне - мова твораў І. Яцкоўскага і мова ягоных лістой. Бо якраз у польскамоўных лістах пісьменніка захаваліся шматлікія "правінцыялізмы”. Больш адукакаваны Л. Нядзвецкі часам папраўляў сябра, папраўляў недакладнасць словаўжывання, на што I. Яцкоўскі адказваў: Пішу, як навуиьла мяне мачі. Даволі часта ён выкарыстойвае прыказкі і прымаўкі, большасць з якіх маюць беларускае паходжанне. Вось некаторыя з іх: Паехаў вазамі без коней, Маё шиьрае жаданне, каб прусак пабіў маскаля $i$ аўстрыяка, а яго самога забіў пярун, Служьи пану верне, то ён табе пердне, Спяваць дармо, балічь гардло, I воўк будзе сыты, і козы чэльля, На злодзеі шапка гарыџь, Не плюй у ваду, бо можа здарыииа табе яе напічиа.

\section{4. Магчымае "выкарыстанне" I. Яцкоўскім першага радка верша Тамаша Аўгуста Алізаройскага.}

I. Яцкойскі дазваляў сабе ў паэтычнай творчасці выкарыстойваць матывы, вобразы і асобныя выразы вершаваных твораў сучаснікаў. На жаль, мы даволі кепска ведаем эміграцыйную паэзію, а таму можам падаць толькі асобныя прыклады наследавання I. Яцкоўскага.

42 Stownik jezyka polskiego, red. W. Doroszewski, Warszawa 1963, t. V, s. 540.

43 Тлумачальны слоўнік беларускай мовы ў 5-ці тамах, Мінск 1983, т. I, с. 94. 
Адзін з самых цікавых - падражанне аўтара беларускага верша Т.А. Алізаройскаму. Дакладней, не падражанне нават, а - хутчэй неўсвядомленае паўтарэнне-перайманне пачатковых слоў верша, які захаваўся ў дзвюх версіях.

Першая версія была напісана у 1841 годзе і пад тытулам "Wiersz Olizarowskiego do A... М..." надрукавана ў газеце "Dziennik Narodowy":

Zagraj, zagraj a zaśpiewaj

Pieśniareńku Lacki nasz!

Z serca w serce pieśń przelewaj -

Świętą pieśnią Cara strasz.

(...)

No! pieśniaru, nie|zamieraj!

W żywo struny hurra dzwoń -

A ty czasie w łańcuch zbieraj

Serce z sercem, z dłonią dłoń ${ }^{44}$.

Гэта быў ужо другі верш-зварот Т.А. Алізароўскага да А. Міц-

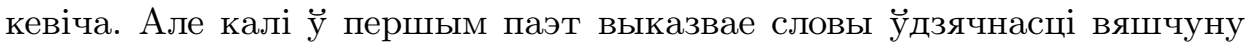
за тое, што Blask twego geniuszu przeszedt po mych piórach, //Wybił ze snu me skrzydta ${ }^{45}$, дык у другім заклікае яго больш актыўна спяваць дзеля абуджэння змагарой за вольнасць краю ${ }^{46}$.

Яшчэ больш выразна дадзены матыў гучыць у другім варыянце твора, які быў напісаны, магчыма, для Багдана Юзафа Залескага (1802-1886). Называўся ён "Przynuka": сармацкі звычай прынукі (прымусу) госця есці і піць за сталом дастасаваны тут да заахвочвання пісаць высокапатрыятычныя тэксты. Ад папярэдняга варыянту Т.А. Алізароўскі пакінуў (адпаведна змяніўшы) першую і апошнюю строфы, а замест трох, што былі ў сярэдзіне, напісаў пяць новых:

Zagraj, zagraj a zaspiewaj

Ukraiński piewco nasz!

Z serca w serce pieśń przeléwaj:

Swiętą pieśnią cara strasz.

$(\ldots)$

44 [T.A. Olizarowski], Wiersz ... do A... M..., "Dziennik Narodowy" 1841, nr 32 (6 listopada).

45 O., Wiersz do ..., "Dziennik Narodowy" 1841, nr 23 (4 września).

46 Варта звярнуць увагу на тое, што на Т.А. Алізароўскага мог паўплываць 108 псалм (ва ўсходняй традыцыі - 107) цара Давіда: Gotowe jest serce moje, Bo$\dot{z}$ e, // zaśpiewam i zagram. // Zbudź się, chwało moja, // zbudź się, harfo i cytro! // Chce obudzić jutrzenke. 
Piewco ruski nie|zamiéraj:

W żywostruny hurra dzwoń.

A ty czasie w łańcuch zbiéraj

$\mathrm{Z}$ sercem serce, z dłonią dłoń ${ }^{47}$.

Не выклікае сумневу, што І. Яцкойскі добра ведай творы свайго калегі і прыяцеля Т.А. Алізаройскага (пра гэта сведчыць напісаны у 1849 г., а у 1852 г. надрукаваны верш). А паўтарэнне ім у беларускамойным творы пачатковых слой верша (дзе, заўважым, сустракаюцца ўкраінізмы) тлумачыцца наступным: словы, якія моцна "ўкараніліся" ў памяць І. Яцкойскага і якімі ён мог пачаць маналог сялянскага хлапчука Пётрака, аніяк не станавіліся плагіятам, бо былі нібыта напісаны 25 гадоў таму.

Трэба яшчэ зайважыць, што ў вершах (магчыма, так будзе больш правільна: твор адрасуецца розным асобам) Т.А. Алізароўскага матыў-просьба, матыў-зварот зайгращь $\boldsymbol{i}$ заспяващь з'яўляецца вызначальным, ім прасякнуты ўвесь тэкст; ігранне $\boldsymbol{i}$ спяванне прызнаных майстрой слова павінна служыць важнай мэце і выканаць важную функцыю - сабраць "сэрцы і далоні" дзеля перамогі над ворагам. А вось у беларускамоўным творы дадзены матыў, моцна выяўлены у першай страфе, пасля - фактычна "знікае", замяняецца матывам уцёкай лірычнага героя 3 роднага краю, бо жыць тут становіцца немагчыма. А таму матыў іграння выконвае ў беларускамоўным вершы адно функцыю сігнальную, функцыю паведамлення пра невыноснасць жыцця на бацькайшчыне.

Вядома, можна сказаць, што аднолькавыя пачатковыя словы ў беларускім вершы і у у творы(ax) T.А. Алізаройскага - з'ява выпадковая. Але ці не занадта шмат "выпадковасцяў” у праблеме атрыбуцыі славутага тэкста?

\section{5. Выкарыстанне літаратурнага прыёму: калі ̈̈ творы адзін з герояў мусіць "выказацца" вершам, дык айтар сам піша неабходны тэкст.}

Дадзены аргумент мае сваю вагу толькі ў тым выпадку, калі мы лічым кнігу I. Яцкоўскага мастацкім творам, а не ўспамінамі.

Варты ўвагі той факт, што наваградчанін у сваім рамане ўсяго некалькі разоў падае вершаваныя радкі. (Як на аматара паэзіі, дык і няшмат). Напачатку ён недакладна цытуе два апошнія радкі паэмы

47 T.A. Olizarowski, Woskresenki, Paryż 1846, s. 31-32. 
"Манахамахія" Ігнацы Красіцкага; пасля - чатырохрадкоўе-эпітафію пэўнага святара з вёскі Дзевянтковічы на Слонімшчыне:
Za owcami Pasterz swemi
Musi także pójść do ziemi,
Dajże Boże temu zdrowie,
Kto nam WIECZNY POKÓJ powie.

I, нарэшце, “некалькі строф", што засталіся ў памяці, крашынскага Пётрака.

Сэнс выказвання I. Красіцкага пісьменнік крышку змяніӱ, але ў дадзеным выпадку не можа быць гаворкі пра нейкую містыфікацыю. А вось ужо наступны ягоны зварот да "паэзіі" - цалкам магчыма створаны фантазіяй I. Яцкоўскага: раманісту тут неабходна паказаць тую катастрофу на Бацькаўшчыне, якая была наступствам як французскае навалы, так і пошасці, выкліканай гэтаю навалаю. Вядома, у памяці пісьменніка маглі захавацца звесткі пра тое, як вясковы ксёндз-пробашч загадаў выбіць на помніку эпітафію ахвярам страшнага 1812 года але вось ці памятай ён той тэкст некалькі дзесяцігоддзяў? Сумнеўна, хутчэй сам напісаў яе. Нешта падобнае магло здарыцца і са "строфамі” крашынскага Пётрака.

\section{6. Як відавочны факт трэба ўспрымаць тое, што І. Яцкойскі не валодаў такой памяццю, каб цягам 25 гадой “трымаць у галаве" нібыта пачуты колісь беларускамоўны верш крашынскага падлетка.}

Пра следчую справу адносна Крашынскае школы I. Яцкоўскі мог ведаць з 1828 года. Ці мог ён захаваць у памяці верш, які нібыта пачуй чвэрць стагоддзя таму?

Сучаснікі сведчаць, што Ігнацы Яцкоўскі меў выключную памяць:

Яцкоўскі - гэта добры праўнік, мае невычарпальны запас авантур, показак, анекдотай, у якіх табе падасць прозвішчы асоб, з імёнамі, узростам, датамі, памятае, ці тое дзеялася з суботы на нядзелю, ці ў саму нядзелю, якое было надвор'е. Калі гаворка пра куплянне, дык памятае ўсіх пакупнікоў, памятае сумы, якія заплацілі, якога дня і дзе. Здзівішся, калі табе скажу, што няхай табе сто разой паўторыць, а заўсёды тое самае памяць незвычайная і багацце дэталяй. Асобныя з яго аповесцяў былі такія цікавыя, што я, памятаю, запісай іх быў некалькі. Ведай, я заахвочвай Яцкойскага, каб узяўся за пяро і запісаў нам, калі можа, усё, што ведае, што нам расказаў. Заахвочванне, здаецца, толькі абуджала тое, што на дне яго думкі ляжала. Ён усміхнуўся, як смяецца задавальненне, і не разва- 
жаючы, сказаў, што зробіць гэта напэўна. А што больш, нібыта скрытна казаў, што можа лепш напіша за Сапліцу ${ }^{48}$.

Каб І. Яцкойскі пісай успаміны, дык, вядома, ён мусіў бы імкнуцца да дакладнасці, але выбраўшы дзеля выкладу матэрыялу жанр рамана, мог адвольна інтэрпрэтаваць факты рэчаіснасці. У гэтым няцяжка пераканацца, параўнойваючы малюнкі рамана з друкаванымі дакументамі таго часу - афіцыйнымі адрас-календарамі ("Мちсяцословъ съ росписью чиновныхъ особъ, или Общій штатъ Россійской Имперіи на ль̆то...").

Возьмем, напрыклад, аповед І. Яцкойскага пра ўцёкі ліцвінскае моладзі напачатку XIX стагоддзя ў войска Напалеона. У гэтай гісторыі ці не галойнай дзейнай асобай стаўся наваградскі спраўнік Пётр Пятровіч. I сапраўды ў Наваградку з 1805 г. па 1828 г. пасаду спраўніка займай Пётр Пятровіч Берг, які напачатку меў чын калежскага асэсара - чынойніка VIII класа (відавочна, раней, у войску быў ротмістрам ці штабс-капітанам). Трапіў у Наваградак П.П. Берг, хутчэй за ўсё дзякуючы свайму саноўнаму сваяку - сапрайднаму стацкаму саветніку (IV клас) Пятру Іванавічу Бергу, які напачатку XIX стагоддзя займай пасаду гродзенскага віцэ-губернатара.

Сумленны і шляхетны П.П. Берг фактычна выратоўвае ад рэпрэсій шэраг вядомых наваградскіх сем'яў. Так у кнізе. Магчыма, гэтак было і $\ddot{y}$ рэальнасці. Праверыць тое мы не можам. Але сёе-тое не адпавядае малюнку, створанаму І. Яцкойскім: ордэн св. Анны, нягледзячы на сцверджанне I. Яцкойскага, П.П. Берг у 1811-1812 гг. не атрымліваў. Перадусім, толькі ў 1816 г. ён займеў ранг надворнага саветніка (VII клас) і ордэн св. Уладзіміра 4 ступені, а ў 1820-я гг. ордэн св. Анны 3 ступені.

П.П. Берга, відавочна, І. Яцкойскі добра ведай. Пэўна, ведаў і пра атрыманы ім ордэн св. Анны. Але чаму ён "узнагародзіў” спраўніка у 1811 годзе? Відавочна, гэтага вымагала мастацкая праўда рамана.

3 гэтаю ж самаю гісторыяй звязаны яшчэ адзін персанаж кнігі I. Яцкойскага. Бясспрэчна, вобраз сакратара Казіміра Матовіча таксама меў свой рэальны прататып. Праўда, і тут I. Яцкоўскі не зусім дакладны. Казімір, сын Юзафа Матовіч (у І. Яцкойскага - сын Габрэля) у календарах звычайна называецца Козьма Осипов Мотович і толькі у звестках 1830-х гадоз̆ - Казимир Осипов Мотович. Але справа ў тым,

48 L. Niedźwiecki, Listy wybrane z lat 1832-1839, oprac. St. Makowski, Warszawa 2009 , s. $580-581$. 
што ён ніколі не быў сакратаром Ніжняга Земскага суда ў Наваградку. Гэтую пасаду ад пачатку XIX стагоддзя да сярэдзіны 20-х гадоў займаў тытулярны саветнік Герасім Сачава-Дзяшчынскі (прозвішча ў календарах падаецца ў шматлікіх варыянтах). А страпчым ад пачатку стагоддзя да 1815 года быў расеец Іван Іванавіч Грабаў. Паводле адрас-календарой, губернскі сакратар (XII клас) К. Матовіч толькі у 1815 годзе займае пасаду страпчага ў Наваградскім Земскім судзе. Ці не азначае гэта, што I. Яцкоўскі, у мастацкім творы не лічыў патрэбным слепа прытрымлівацца храналогіі падзей? Відавочна, ён "тварыў" з вядомых яму "дэталяў” неабходныя камбінацыі і фігуры, каб давесці тую ідэю, якая была вельмі важнай для яго.

Падобную "інтэрпрэтацыю" гістарычных (i перш за ўсё жыццёвых) здарэнняў І. Яцкойскі будзе практыкаваць цягам усяго свайго рамана. Чарговае параўнанне лёсаў рэальных людзей з вобразамі “Аповесці з майго часу" можа пацвердзіць гэтую думку.

Напрыклад, у адным з раздзелаў свае кнігі І. Яцкоўскі піша, што у 1811 годзе прэзідэнтава Пацыніна, удава, утрымлівала ў Наваградку нешта накшталт пансіёну - брала на выхаванне шляхецкіх дачок. Апрача гэтага, мы даведваемся, што яе муж быў да падзелаў Рэчы Паспалітай гараднічым у Наваградку. Пасля змены ўлады ён застаўся без пасады, але калі пры Паўлу I дазволілі шляхце выбіраць дробных службоўцай, дык Пацына стай "прэзідэнтам гродскім", г. зн. прэзідэнтам Гродскага суда ў Наваградку. Праз некалькі гадой Пацына памёр, пакінуйшы ўдаву без сродкаў да існавання. Тады ёй на дапамогу прыйшлі сябры мужа - Францішак Пілецкі, Тадэвуш Гаціскі і Тадэвуш Чачот, якія купілі ёй двор на Базыльянскай вуліцы.

I мы мусім верыць I. Яцкоўскаму, бо ягоны тэкст - успаміны. Бо ён валодаў незвычайнаю памяццю. Бо ён, верым мы, дакладны ў дэталях.

А цяпер прыгледзімся, ці пацвярджаецца гэтая гісторыя адрас-календарамі. Кім быў Пацына да падзелаў краю, нам высветліць пакуль не ўдалося. Першая вядомая нам згадка пра яго датуецца 1802 годам: Леон, сын Фларыяна Пацына займае пасаду асэсара (засядацеля) у Ніжнім земскім судзе $\breve{y}$ Наваградку. Верагодна, ён якраз у часы Паўла I апынуўся на службе ў дадзенай установе. У наступным годзе мы бачым яго ӱжо на пасадзе камісара Ніжняга земскага суда (крыху пазней змянілася найменне пасады: замест камісараў з'явіліся спраўнікі ці капітан-спраўнікі). I Л. Пацына будзе займаць гэтую пасаду цягам трох гадоў. А з 1806 годзе ён у складзе Гродскага суда, прэзідэнтам якога з'яўляецца Міхал Куневіч, суддзямі (разам з ім) Матэвуш Маркевіч, Эраст Кміта, а пісарам - Казімір Мацкевіч. 
На наступных выбарах (1809 год) Л. Пацыну абіраюць прэзідэнтам Гродскага суда (суддзямі - Тадэвуша Гаціскага, Яна Слізня і Стафана Багдашэўскага, пісарам - Фелікса Яблонскага). Дадзеная інфармацыя надзвычай каштойная - Л. Пацына ў часы Напалеонаўскай вайны мог жыць у Наваградку!

Звестак пра Л. Пацыну пасля 1812 года адшукаць не ўдалося. Цяжка сказаць: ці памёр ён у гэты час, ці проста пакінуў службу. У Гродскі суд прыйшлі іншыя людзі: прэзідэнтам стаў Казімір Мацкевіч, суддзямі - Ян Забела, Аўгуст Сакаловіч і Ігнацы Туганоўскі, пісарам - Эраст Кміта. Зноў узнікае пытанне, чаму наваградскія здарэнні відавочна пазнейшага часу I. Яцкоўскі пераносіць у 1811 год?

Фактычна тое самае пытанне ўзнікае і пры аналізе звестак з календарой адносна гродзенскага цывільнага губернатара. Ім у 1803-1812 гадах быў Васіль Сяргеевіч Ланской (1753-1831) ${ }^{49}$, але ён, стаўшы у 1809 годзе сенатарам, выехаў з Гародні і толькі фармальна лічыўся цывільным губернатарам да красавіка 1812 года.

Гэта азначае, што не $\breve{y} 1811$ годзе, а $\breve{y ~ 1807-1808 ~ г а д а х ~ н а в а г р а д с к а я ~}$ моладзь уцякала да Напалеона і наваградскі спраўнік Пётр Пятровіч Берг мог даручыць сакратару Ніжняга земскага суда Герасіму Сачава-Дзешчынскаму (але не Казіміру Матовічу!) напісаць лісты да гродзенскага цывільнага губернатара В.С. Ланскога. Магчыма, гэтую гісторыю І. Яцкойскі пачуй ад Казіміра Матовіча, які хоць і не быў сакратаром, але мог служыць у канцыляры Ніжняга земскага суда. I менавіта ён мог паспрыяць наваградскім абывацелям. Аднак відавочна тое, што пасаду страпчага Казімір Матовіч атрымаў не ў сувязі з гэтай гісторыяй і пазней, у 1815 годзе, калі гродзенскім цывільным губернатарам быў Карл Карлавіч Ляшэрн.

Гэтыя, здавалася б, дробныя дэталі яшчэ раз пацвярджаюць нашыя сумневы, адносна дакладнасці аповеду І. Яцкойскага. Ягоны тэкст пра часы, калі ён быў у дзіцячым веку, мае характар мастацкі, а не мемуарны.

Надзвычай цікавым можа быць аналіз звестак пра прататыпай крашынскае гісторыі І. Яцкоўскага. Пісьменнік адной з прычынаў канфлікту двара і вёскі ў Крашыне, спасылаючыся на нейкіх "адных", лічыў тое, што ксёндз В. Магнушэўскі не мог спакойна глядзець на шлюб убогага шляхціца пана Юрагі з князёўнаю Антанінаю Радзівіл.

49 А не яго старэйшы брат Мікалай Сяргеевіч Ланской (1746-1812), як сцвярджалі мы ў каментарах да выдання беларускага перакладу “Аповесці з майго часу” (2010). 
Вядома, пасля падзелаў Рэчы Паспалітай кожны, раней нават самы заможны, мог стаць убогім. Магчыма, пасля напалеонаўскай вайны Станіслай Юрага і быў убогім. Але адно пэўна: ён быў прадстаўніком арыстакратычнага роду - належаў да князёў Гедройц-Юрагаў. Паказальна: яго дачка была запісана як князёўна Тэафілія Гедройц гербу ўласнага. Ці мог ксёндз Магнушэўскі з пагардаю ставіцца да прадстаўніка княскага, хоць беднага роду?

Трагічным для сям'і Юрагай-Радзівіл стаўся 1851 год.

У 1851 годзе памерлі: фактычны “арганізатар" сялянскага бунту Станіслаў Казімір князь Юрага гербу Гедройц (каля 1790-1851), яго жонка - Антаніна Людвіка Тэафілія князёўна Радзівіл на Нясвіжы гербу Трубы (19.12.1790-1851) і дачка - князёўна Тэафілія Гедройц гербу ўласнага (17.10.1822-13.03.1851).

26 мая 1850 года, за дзевяць з паловаю месяцаў да смерці, Тэафілія Гедройц нарадзіла дачку (гэта было яе пятае дзіця) Марыю Тэафілю Эўгенію Святаполк-Завадскую гербу Ліс (1850-1920). Муж Тэафілі Гедройц, Эўгеніюш Роберт Святаполк-Завадскі гербу Ліс (1817-1880), да княскага роду не належаў. Як і іх сын - Пётр Станіслаў Вацлаў Святаполк-Завадскі гербу Ліс (03.06.1847 - пасля 1884).

Магчыма, атрымаўшы з бацькайшчыны вестку пра гэтую трагедыю, І. Яцкойскі ўключыў у сваю кнігу аповед аб крашынскіх хваляваннях 1828 года.

\section{7. Трэба лічыцца з тым фактам, што I. Яцкоўскі, ідучы на паўстанне, не мог забраць з сабою ўласны архій i, тым больш, захаваць яго ў невыносных, часам, умовах паўстан- чага, а пасля тулячага жыцця ў Еўропе.}

Да Літоўскага паўстання І. Яцкоўскі далучыўся вясною 1831 года як паручнік "атрада навагрудскай конніцы". Цяжка сказаць, наколькі ён быў падрыхтаваны да паўстанцкага жыцця, але вось грошай з сабою не забраў: царская ўлада $\ddot{\mathrm{y}} 1833$ годзе канфіскавала ягоны наличный капитал 600 рублей ассигначиями, што знайшоўся ў маёнтку Малюшыцы пана Дубічынскага ${ }^{50}$. Малавыгодным быў ягоны трохмесячны побыт у атрадзе Юзафа Кашыца (ці Францішка Міцкевіча), а пасля у корпусе генерала Генрыка Дэмбінскага, калі паўстанцы з баямі прарываліся да Варшавы.

50 Гл.: "Dodatek pierwszy do gazety Kuryera Litewskiego" 1833, nr 96 (16 sierpnia v. s.). 
А яшчэ $\breve{~ г о р ш ы х ~ у м о в а х ~ а п ы н у и ̆ с я ~ І . ~ Я ц к о и ̆ с к і ~ п а с л я ~ т а г о, ~ я к ~}$ у верасні 1831 года пакінуў Варшаву, якая капітулявала, і мусіӱ ратавацца ад расейскага войска. Спачатку ён хаваўся у Кракаве, але аўстрыйскія ўлады $\breve{y}$ хуткім часе інтэрнавалі яго і выслалі $\ddot{y}$ Галіцыю (магчыма, дзеля пазнейшае перадачы расейскім уладам). Доўга ягоны лёс заставаўся няпэўным, і толькі позняй восенню 1833 года па дамоўленасці з Францыяй аўстрыйцы пачалі дэпартацыю былых паўстанцаў з Галіцыі. Іх сабралі у Трыесце, у замку пад аховай войска. Расія дамагалася выдачы сваіх грамадзян-злачынцаў, але тамтэйшы французскі консул Левасэр (Levasseur) зрабіӱ усё магчымае, каб паўстанцы атрымалі дазвол на выезд у Францыю. Нягледзячы на тое, што французскія ўлады не жадалі болей прымаць уцекачоў, Левасэр выдаваў ім французскія пашпарты, нават не патрабуючы доказаў пра наяўнасць "маёнтку" - сродкаў на жыццё ў Францыі. Аднак аўстрыйскія ўлады вырашылі вывесці ўцекачой у Злучаныя Штаты Амерыкі ${ }^{51} .18$ верасня 1833 года I. Яцкойскі мусіў плысці ў ЗША ${ }^{52}$, але 3 невядомай прычыны толькі 5 снежня 1833 года на брыгу "Рэгіна" разам з 30 афіцэрамі ён быў накіраваны у Марсель, куды прыплыў 15 студзеня 1834 года. Мясцовыя ўлады перасадзілі уццекачоў на ваенны карабель "Malouine", каб везці, нягледзячы на пратэсты эмігрантаў і нават жыхарой Марселя, у Алжыр, у французскі замежны корпус ${ }^{53}$. I. Яцкоўскі трапіў у Аран (правінцыя у Алжыры, з 1831 г. - калонія Францыі), дзе 10 красавіка 1834 года прасіў дазволу выехаць праз Францыю ў Польшчу ${ }^{54}$. Відаць, дазвол ён атрымаў, але з Францыі накіраваўся не на радзіму, а ў Англію, урад якой у гэты час абвясціў, што будзе даваць дапамогу польскім уцекачам ${ }^{55}$.

Перапетыі жыцця I. Яцкоўскага 1831-1834 гадоў не дазваляюць меркаваць, што ён мог мець пры сабе шмат рэчай. Тым больш - цалкам непатрэбны эмігранту аркуш паперы з беларускамоўным вершам крашынскага падлетка.

51 R. Bielecki, Zarys rozproszenia wielkiej emigracji we Francji, Warszawa-Łódź 1986, s. 19 .

52 R. Bielecki, Stownik biograficzny oficerów Powstania Listopadowego, Warszawa 1996, t. 2 , s. 184 .

53 R. Bielecki, Zarys rozproszenia Wielkiej Emigracji we Francji, Warszawa-Łódź 1986, s. 19 .

54 Ibidem.

55 В. Гарбачова пра гэты этап жыцця I. Яцкойскага піша так: Пасля заканчэння ваен. дзеянняў хаваўся ў Кракаве, інтэрніраваны. 18.9.1833 выехаў з Трыеста ў Паўночную Амерыку. У студз. 1834 апынуйся ў Англіі. Гл.: В. Гарбачова, Удзельнікі паўстання 1830-1831 ге. на Беларусі, Мінск 2006, с. 385. 
8. Але ці не самым важным аргументам, які "схіляе" да аўтарства I. Яцкойскага, з'яўляецца рытмічная арганізацыя верша “За́грай, за́грай...”.

На жаль, мала хто з беларускіх літаратуразнаўцаў звяртаўся да праблемаў версіфікацыі “За́грай, за́грай...”. Толькі ў 1973 годзе, фактычна ўпершыню, Мікола Грынчык ахарактарызаваў твор П. Багрыма ў кнізе "Шляхі беларускага вершаскладання" з пункту гледжання ягонай метрыкі і рытмікі. Ён звярнуў увагу, што напачатку XIX стагоддзя у беларускай паэзіі назіраецца адначасовае узжыванне дзвюх сістэм вершаскладання - сілабічнай і танічнай, а у творчасці П. Багрыма адбываецца аб'яднанне дзвюх гэтых сістэм. На думку М. Грынчыка, першая страфа верша напісана ў традыцыйна-сілабічнай форме: Дакладна захавана ройнаскладовасчь бесчэзурнага васьміскладовіка. Парнасць рыфмоўкі тут падмачоўваециа нават пры дапамозе так званай пераакчэнтойкі, гэта значьць падгону натуральнага начіску пад пануючую схему жаночай рыфмойкі ("ма́лы - чьмба́ль”", замест маль́, “дудду - бу́ду", замест дуду́ $і$ інш.).56.

Заўважым: дадзеная выснова памылковая. А прычына недакладнасці, відаць, тая, што М. Грынчык дзеля аналізу верша П. Багрыма карыстаўся адаптаванай версіяй твора. Адаптацыя ж у першай страфе пераіначыла ейны рытмічны малюнак: зайгра́й (двойчы) замест záhraj, скрб́ппачку замест skrypáczki, Kро́шыне замест Kraszýnie і інш.

У далейшых сваіх разважаннях, патлумачыўчы дадзены "сілабізм" П. Багрыма "класамі" (г. зн. навучаннем у школцы) В. Магнушэскага, даследчык бачыць у вершы “танічны прынцып" як выяўленне самабытнай індывідуальнасці самародка-паэта, адзнакі яго выключнай творчай інтуіиыі і развітага эстэтычнага густу і характарызуе “За́грай, за́грай..." як народна-песенны двухакиэнтны танічны верш".

Праўда, М. Грынчык заўважыў у “За́грай, за́грай...” адначасна і харэічную кадэнцыю. Прычым, нават у першай страфе, якая раней характарызвалася ім як бесцэзурны васьміскладовік. Харэічны памер, на думку даследчыка, набывае $\check{y}$ II, III, IV строфах xарактар выразна метрычны, закончаны, сіметрычны $i$ не думаециа, каб выпадковы. У падборы $і$ вар'іраванні рытмічных элементаў заўважаечиа імкненне да раўначленнасці і размеранасці стоп, часам нават шляхам

56 М. Грынчык, Шляхі беларускага вершаскладання, Мінск 1973, с. 88.

57 Тамсама, c. 89. 
пераакцэнтойкі, гэта значьць сінтаксічнага, інтанаџыйнага «падгону» асобных стоп (...) харэічная стыхія з'яўляечиа тут пануючай. $\ddot{Е ̈ и ~ п а д п а р а д к а в а н ы ~ п і р ы х і і, ~ а ~ т а к с а м а ~ ш м а т л і к і я ~ п р ы е ̈ м ы ~ т р а н с-~}$ акцэнтацыі («ся́стра» замест сястра́, «па́йдy»-nайдý, «мя́не»мяне́ $і$ інш.). ${ }^{58}$.

Задумваючыся над надзвычай складаным, на думку даследчыка, рытмічным малюнкам верша, М. Грынчык незаўважна нават для самога сябе "залічыў" І. Яцкоўскага ў суаўтары да П. Багрыма: Maгublма, перанос акцэнтаў звязан тут з абставінамі вуснага ўзнаўлення твора Яикоўскім, які мог прыўнесці уัласную трактоўку рытмічнага ладу забытага верша Багрыма"59. (Згадзіцеся, "узнаўляльнік", які надае вершу новы рытмічны лад - гэта і ёсць суаўтар!).

Праўда, тут жа М. Грынчык палічыў патрэбным патлумачыць версіфікацыйныя прыёмы беларускага аўтара П. Багрыма ўзмацненнем (хачя ўсе знешнія абставінь выразна супрацьдзейнічалі гэтаму) танічнага прынцыпу вершаскладання і тым, што малады nаэт не пайшоў пратаптаньмі сцежкамі, а звярнуўся да зусім нераспрачаваных $i$, відавочна, новых у той час рытміка-інтаначыйных форм, інтуітыучна арыентуючыся на фальклорныля традыцыібі.

Фактычна, у дадзенай працы ледзь не адназначна сцвярджалася, што пятнаццацігадовы П. Багрым быў адным з першых, хто ўвёў у беларускую паэзію сілаба-тоніку. Пэўную "ролю" мог у гэтым, - нясмела дапускаў М. Грынчык, - адыграць I. Яцкоўскі.

Такое "неадпаведнае" дапушчэнне М. Грынчыка аспрэчыў у 1977 годзе I. Ралько у працы "Вершаскладанне: даследаванні і матэрыялы". (Пазней паўтарыў тое самае ӱ грунтойнай манаграфіi "Верш і мова”). Ён, карыстаючыся тэкстам “За́грай, за́грай...” непасрэдна 3 пазнанскага 1858 года выдання "Аповесці з майго часу...", катэгарычна сцвердзій: твор напісаны $\breve{y}$ харэічным рытме $з$ арыентацыяй на музычнае суправаджэнне. Пры гэтым, І. Ралько, як і М. Грынчык, звярнуў увагу на наяўнасць пераакцэнтуаџыі як сродку захавання харэічнае кадэнцыі $і$ адначасова водгуку пэўнага ўлльву акчэнталогіi польскай мовы ${ }^{61}$. Вядома, польскае мовы П. Багрыма.

58 Тамсама, с. 89-90.

59 Тамсама, с. 90.

60 Тамсама, с. 90-91.

61 І. Ралько, Верш і мова: Праблемь тэорыі і гісторьі беларускага верша, Мінск 1986, c. 14. 
Свае высновы даследчык пацвярджае і тым, што пераклад верша, выкананы I. Яцкойскім, вельмі дакладны $і$ пойнасцю вытрылманы у харэічным рытме. Аднак калі у багрымаўскім тэксче інериыя харэічнага рытму иягне за сабой неабходнасчь акчэнтавання граматычна не акцэнтаваных складоў, то у перакладзе I. Ячкоўскага метрычныя акцэнты ўсюды супадаючь з граматычнымі - памер строга вытрымліваециа. Факт гэтыл, несумненна, сведчьць пра тое, што I. Ячкоўскі успрылаў рытм багрымаўскага верша як харэічны ${ }^{62}$.

Думка I. Ралько пра харэічны рытм верша "За́грай, за́грай..." вельмі істотная. Але не менш важным з'яўляецца і выснова даследчыка пра тое, што $\breve{y}$ беларускім тэксце дзеля харэічнага рытму выкарыстоўваецца пераакцэнтуацыя, у тым ліку і пад ўплывам акцэнталогіі польскае мовы.

Сам I. Ралько не падаў аніводнага прыкладу пераакцэнтуацыі у вершы П. Багрыма. Не паставіў націскі ён і тады, калі перадрукойваў у сваёй працы транслітэраваны з лацінкі на грамадзянскі шрыфт тэкст твора. Чаму? Магчыма, таму, што выразна кідалася ў вочы даволі частае небеларускае вымаўленне беларускіх слой.

На нашу думку, у вершы “За́грай, за́грай..." пераакцэнтуацыя закранула дваццаць адно слова. Як на сто трыццаць (улічваючы службовыя часціны мовы) слой верша, дык і нямала - 16,15\%. Пададзім іх у наступнай табліцы:

$\begin{array}{ll}\text { Паводле Anовесиi... } & \text { Беларускае } \\ (1858) & \text { вымаўленне } \\ \text { Záhraj } & \text { Зайгра́й } \\ \text { máły } & \text { маль́ } \\ \text { skrypáczki } & \text { скри́пачка } \\ \text { záhraju (?) } & \text { зайгра́ю } \\ \text { u dúdu } & \text { у дудý } \\ \text { kíjami (?) } & \text { кія́мі } \\ \text { siástra } & \text { сястра́ } \\ \text { pájdu } & \text { пайдý } \\ \text { miánie } & \text { мяне́ } \\ \text { Szczáśliǔszaja (?) } & \text { Шчаслі́ушая } \\ \text { U pańszczýnu } & \text { У па́́шчыну } \\ \text { U rekrúty } & \text { У рэ́круты } \\ \text { ú Maskáli } & \text { у Маскалі́ } \\ \text { pastúszkom } & \text { пастушко́м }\end{array}$

Заўвагі

польск. zágraj (двойчы) польск. máły польск. skrzypéczki польск. zágram польск. na dúdzie польск. kijámi польск. sióstra польск. pójdę (двойчы) польск. mnie (двойчы) польск. Szczęślíwszą польск. W pańszczýznę польск. W rekrúty польск. w Moskále (двойчы) польск. pastúszkem

62 Tамсама, с. 15. 
każánie

Czámuż

na mnié кажане́

Чаму́ ж

на мяне́ польск. сzémuż

польск. ná mnie

Як бачна, васямнаццаць разоў (як выключэнне, - kíjami i Szczáśliǔszaja) тут, магчыма, ужываецца дыялектная форма, ці аўтар свядома, дзеля захавання рытму, парушае акцэнталогію беларускае мовы. А таксама запазычвае, думаецца, з фальклору прычытанне $O j$, każánie, każanié! // Czámu|ż nia siǔ ty ná mnie?) з дваццаці аднаго пераакцэнтуаванага слова знаходзяцца ў пэўнай залежнасці ад акцэнталогіi польскае мовы. Не забывайма і пра неўласцівыя беларускай мове звароты: Hdzie|z ty pojdziesz (замест - куды ты пойдзеш), bez Panow abyйsia (ад польск. оbyć się - абыйсціся, даць сабе рады), na was abziarnusia (ад польск. obzierać się - аглядацца), Hdzie|ż ja biedny abiarnusia (гл. вышэй). А гэта можа сведчыць і пра дастаткова неглыбокае валоданне аўтарам беларускаю моваю, і пра яго добрае веданне польскае мовы. У выпадку з П. Багрымам павінна было б быць якраз наадварот.

Цікавым для нас можа быць і тое, што у з запісанай П. Багрымам для чыноўніка Я. Нечвалодава "Rozmowie Chłopow" выразна выяўляюцца, прыўнесеныя ім, П. Багрымам, у тэкст Я. Баршчэўскага, наваградскія дыялектныя асаблівасці (dzieciukie, palakie, pane, dware); у той жа час у творы цалкам адсутнічаюць паланізмы (апрача, хіба, тытулу).

Калі ж працягваць настойваць на аўтарстве верша "За́грай, за́грай..." П. Багрыма, дык застаецца адно дапусціць, што і рытмічны лад, і падмена слоў (ці радкой нават) у творы ажыццёўлена I. Яцкоўскім. Аднак дадзеную "гіпотэзу" катэгарычна адкінуй яшчэ I. Ралько: Рьıтмічны лад твора, як правіла, застаециа ў памячі нязменным, таксама як музычны напеў дазваляе падмену забытых слоў ці асобных фраз, але падмена гэта не можа пераўтварыщь зыходны рытмічны малюнак напев ${ }^{63}$.

Харэічны рытм дзевятнаццаці радкой верша “За́грай, за́грай...” "трымаецца" на выкарыстанні пераакцэнтуацыі, якая ледзь не цалкам абапіраецца на акцэнталогію польскае мовы. 3 аднаго боку, І. Яцкоўскі, як сцвярджае I. Ралько, не мог перамяніць рытмічны малюнак верша на харэічны, а з другога, - П. Багрым, нягледзячы на тое, што вывучыў розныля байкі з Нарушэвіча, Эзопа $i$ «Brukowych Wiadomości», наўрад

63 Tамсама, с. 14. 
ці ведаў польскую мову лепш за сваю родную, а г. зн. не мог стварыць харэічны рытм верша.

Як жа тады ён узнік у дадзеным творы?

Адказ можа быць такі: ён створаны паэтам, асноўнаю моваю якога была польская; і гэта выразна адчуваецца ў вершы “За́грай, за́грай...”, які, па сутнасці, з'яўляецца макаранічным 64 .

А найбольш верагодны аўтар твора - Ігнацы Яцкойскі.

\section{I T E R A T UR A}

Bartkowski J., Wspomnienia z powstania 1831 roku $i$ pierwszych lat emigracji, oprac. E. Sawrymowicz, Kraków 1967.

Bielecki R., Stownik biograficzny oficerów powstania Listopadowego, Warszawa 1996, t. 2 .

Bielecki R., Zarys rozproszenia wielkiej emigracji we Francji, Warszawa-Łódź 1986.

Chaustowicz M., Zahraj, zahraj, chłopcze maly..: prablema autarstwa, [u:] Biełarusika=Albaruthenica 31: Nowaje słowa u biełarusistycy. Litaraturaznaustwa $i$ falkłarystyka: Materyjały $V$ Miżnarodnaha kanhresa biełarusistau, Minsk 2012 [Хаўстовіч М., Заграй, заграй, хлопчэ мальл...: праблема аўтарства, [у:] Беларусіка=Albaruthenica 31: Новае слова уั беларусістыцьл. Літаратуразнаўства і фалькларыстылка: Матэрыяль V Міжнароднага кангрэса беларусістаў, Мінск 2012].

"Dodatek pierwszy do gazety Kuryera Litewskiego" 1833, nr 96 (16 sierpnia v. s.).

Dunin-Marcinkiewicz W., Ciekawyś? - Przeczytaj! Trzy powiastki i wierszyk ulotny, Mińsk 1856.

Harachka H., Zahadki i tajamnicy rodnaj litaratury, [online], http://www2.polskie radio.pl/eo/dokument.aspx?iid=52659 (dostup: 06.01.2017) [Гарачка Г., Загадкі й таямніџь роднай літаратурь, [online], http://www2.polskie radio.pl/eo/dokument.aspx?iid=52659 (доступ: 06.01.2017)].

Harbaczowa W., Udzelniki paustannia 1830-1831 hh. na Biełarusi, Minsk 2006 [Гарбачова В., Удзельнікі паўстання 1830-1831 ге. на Беларусі, Мінск 2006].

Harecki M., Historyja biełaruskaje literatury, Wilnia 1920 [Гарэцкі M., Гicmopьıя беларускае літэратуры, Вільня 1920].

Hrynczyk M., Szlachi biełaruskaha wierszaskładannia, Minsk 1973 [Грынчык М., Шляхі беларускага вершаскладання, Мінск 1973].

64 Макаранічнасць у беларускіх публікацыях "знімалася" як адсутнасцю акцэнтацыі, так і арфаграфічнымі падменамі: звычайна ад 15 да 20 слоў верша папраўлялася рэдактарамі. 
Jackouski I., Apowieść z majho czasu, albo Litouskija pryhody, Warszawa 2010 [Яцкоўскі I., Аповесць майго часу, альбо Літоўскія прыгоды, Варшава 2010].

Janułajcis A., Ab maładym paece z Kroszyna, "Maładaja Biełaruś" 1913, ser. I, ssz. 3 [Янулайціс А., Аб маладым паэие з Крошына, "Маладая Беларусь" 1913, cep. I, сш. 3].

Januszkiewicz J., "A u maskalach trudna życi...": Bahrym-Kraszyn-Jackouskinieumiruczaść: Da 200-hoddzia Pauluka Bahryma i 570-hoddzia Kraszyna, Rakau 2012 [Янушкевіч Я., "А ў маскалях трудна жыці...": Багрым-Крашьи-Ячкоўскі-неўміручасиь: Да 200-годзьдзя Паўлюка Багрьма і 570-годзьдзя Крашына, Ракаў 2012].

Karskij J., Biełorusy, w 3 t., t. 3, kn. 2: Oczerki słowiesnosti biełorusskoho plemieni, Minsk 2007 [Карский Е., Белорусы, в 3 т., т. 3, кн. 2: Очерки словестности белорусского племени, Минск 2007].

Kisialowa L., Z archiwa Hienadzia Kisialowa, [u:] "Paczuć jak losu walacca mury": Pamiaci Hienadzia Kisialowa, Minsk 2009 [Кісялёва Л., 3 архіва Генадзя Кісялёва, [у:] "Пачуць як лёсу валяица мурь": Памячі Генадзя Кісялёва, Мінск 2009].

Korotyński Wł., "Powieść z czasu mojego": Studium literackie, "Kraj", t. XXV, Petersburg 1895, nr 17.

Labaczeuskaja W., Falklarystyczny arhiu Biełaruskaha muzieja imia Iwana Luckiewicza: Wiartannie praz 65 hadou, [u:] "Homo Historicus 2012: Hadawik antrapałahicznaj historyi" 2012 [Лабачэўская В., Фалькларыстыичны архіў Беларускага музея імя Івана Луикевіча: Вяртанне праз 65 гадоў, [y:] "Homo Historicus 2012: Гадавік антрапалагічнай гісторыі" 2012].

Lelewel J., Listy emigracyjne, t. IV: 1849-1861, Wrocław-Kraków 1954.

List I. Jackowskiego do L. Niedzwieckiego z 25.04.1842 r., [w:] Rkps. Kór. 2405: Korespondencja Leonarda Niedźwieckiego: Litera J (Jabtoński Leon - Jung A.), 1832-1874.

Malinouski M., Ci byu Pauluk Bahrym paetam?, "Wo sławu Rodiny" 1992, 9 sient. [Маліноўскі М., Ці бый Пайлюк Багрым паэтам?, "Во славу Родины" 1992, 9 сент.].

Malinouski M., Pawiet Iosifawicz Bahrym (Pauluk Bahrym): Lehiendy, prauda, zahadki, Baranawiczy 2006 [Маліноўскі М., Павел Іосіфавіч Багрылм (Паўлюк Багрылм): Легенды, праўда, загадкі, Баранавічы 2006].

Michałowski A., Trzyletni pobyt na Wschodzie, Londyn 1857.

Niedźwiecki L., Listy wybrane z lat 1832-1839, oprac. St. Makowski, Warszawa 2009.

Niedźwiecki L., Naszych gromadek gadułki, [w:] Rps Kórn, sygn. 2414: L. Niedźwiecki, Materiaty do dziennika z okresu pobytu w Anglii w latach 1831-1839. 
Niekraszewicz-Karotkaja Ż., Szmatmounaja litaratura Bielarusi u kantekcie aktualnych litaraturaznauczych kancepcyj: dapamożnik, Minsk 2015 [Некрашэвіч-Кароткая Ж., Шматмоўная літаратура Беларусі ў кантэксце актуальных літаратуразнаўчыхх канцэпџый: дапаможнік, Мінск 2015].

O., Wiersz do ..., "Dziennik Narodowy" 1841, nr 23 (4 września).

[Olizarowski T.A.], Wiersz ... do A... M..., "Dziennik Narodowy" 1841, nr 32 (6 listopada).

Olizarowski T.A., Woskresenki, Paryż 1846.

Paczynalniki: $Z$ historyka-litaraturnych materyhałau XIX st., uklad. H. Kisialou, Minsk 1977 [Пачыннальнікі: 3 гісторыка-літаратурных матэрыялаў ХІХ cm., уклад. Г. Кісялёў, Мінск 1977].

Piatrok z Kroszyna, "Nasza Niwa" 1911, nr 30 (28 lipienia) [Пятрок з Крошына, "Наша Ніва" 1911, № 30 (28 ліпеня)].

Pigoń S., Pan Tadeusz. Wzrost, wielkość i stawa, Kraków 2002.

Podhorski-Okołów L., Realia Mickiewiczowskie, Warszawa 1999.

Praniewicz H., Chram Bahrymawaha wiersza, [u:] Pauluk Bahrym, Minsk 1994 [Праневіч Г., Храм Багрымавага верша, [у:] Пайлюк Багрыцм, Мінск 1994].

Praniewicz H., "Pan Tadewusz" Adama Mickiewicza i "Apowieść z majho czasu, albo Litouskija pryhody" Ihnata Jackouskaha, "Termapiły" 2016, Nr 20 [Праневіч Г., "Пан Тадэвуш" Адама Мічкевіча $i$ "Аповесиь з майго часу, альбо Літойскія прыгоды” Ігната Яикоўскага, "Тэрмапілы” 2016, № 20].

Ralko I., Wiersz i mowa: Prablemy teoryi i historyi bietaruskaha wiersza, Minsk 1986 [Ралько I., Верш $і$ мова: Праблемы тэорыі $і$ гісторыі беларускага верша, Мінск 1986].

Rypiński A., Poezije, Londyn 1853.

Sierotwiński S., Jackowski Ignacy, [w:] Polski stownik biograficzny, t. X/2, z. 45, Wrocław-Warszawa-Kraków 1963, s. 275-276.

Sudolski Z., Pan Tadeusz w romans przemieniony, czyli Powieść czasu mojego, [w:] Pan Tadeusz i jego dziedzictwo: recepcja, red. B. Dopart, Kraków 2006.

Stownik jezyka polskiego, red. W. Doroszewski, Warszawa 1963, t. V.

Ttumaczalny stounik biełaruskaj mowy и 5-ci tamach, Minsk 1983, t. I [Tлумачальны слоўнік беларускай мовы ў 5-ці тамах, Мінск 1983, т. I].

Zaprudski I., Pytanni atrybucyi, paetyka i estetyka wiersza "Zahraj, zahraj hłopcza maty..., [u:] I. Zaprudski, Narysy historyi bietruskaj litaratury XIX stahoddzia, Minsk 2003 [Запрудскі I., Пьитанні атрыьбуиылі, паэтыка $і$ эстэтыка верша "Зайграй, зайграй хлопча мальл..., [у:] І. Запрудскі, Нарысыь гісторыі беларускай літаратуры ХІХ стагоддзя, Мінск 2003]. 
Zaprudski I., Pa darozie na Parnas: Atrybucyjnyia dasledawanni i pytanni recepcyi biełaruskaj litaratury XIX stahoddzia, Minsk 2012 [Запрудскі I., Па дарозе на Парнас: Атрыбущыйныя даследаванні і пытанні рэцэпцыі беларускай літаратуры ХІХ стагоддзя, Мінск 2012].

Zaprudski I., Skażycie, chto Wy?: Litaraturaznauczyja abrazki, "Pierszacwiet" 1996, N 2 [Запрудскі І., Скажыце, хто Вы?!: Літаратуразнаўчыя абразкі, "Першацвет" 1996, № 2].

Zaprudski I., U poszukach alter ego: Da 170-hoddzia z dnia naradżennia Julana Laskouskaha, "Pierszacwiet" 1996, N 7 [Запрудскі I., У пошуках алтер его: Да 170-годдзя з дня нараджэння Юльяна Ляскойскага, "Першацвет" 1996, № 7].

\section{S U M M A R Y}

\section{IGNATSY YATSKOVSKY AS A PROBABLE AUTHOR OF THE POEM} "ЗА́ГРАЙ, ЗА́ГРАЙ, ХЛОПЧЭ МА́ЛЫ..."

The article discusses the question of the authorship of the poem "За́грай, за́грай, хло́пчэ ма́лы..." in Belarusian literary studies. The main focus is concentrated on the fact that, over the last century, philologists have not been able to establish any convincing arguments to confirm Pavluk Bagrym's authorship of the poem, whereas the investigation of the context in which this work was published allows to claim that Ignatsy Yatskovsky was not only its publisher, but also its author.

Key words: attribution, trochee, rhythm, prosody, emigration, hypothesis, probable author.

\section{S T R E S Z C Z E N I E}

\section{IGNACY JACKOWSKI JAKO PRAWDOPODOBNY AUTOR UTWORU „ЗА́ГРАЙ, ЗА́ГРАЙ, ХЛОПЧЭ МА́ЛЫ...”}

W artykule omówiono zagadnienie autorstwa utworu „За́грай, за́грай, хло́пчэ ма́лы...". Szczególną uwagę zwrócono na fakt, że na przestrzeni ostatnich stu lat filolodzy nie byli w stanie przytoczyć przekonujących argumentów, potwierdzających tezę, że autorem omawianego utworu jest Pavluk Bagrym. Jednocześnie badania kontekstu, w którym utwór powstawał, mogą wskazywać na Ignacego Jackowskiego jako zarówno jego wydawcy, jak i autora.

Słowa kluczowe: przypisanie, trochej, rytm, prozodia, emigracja, hipoteza, prawdopodobny autor. 